\title{
CrimRxiv
}

\section{Harnessing the Power of the Criminal Corpse}

\section{Sarah Tarlow, Emma Battell Lowman}

Published on: Jul 01, 2018

DOI: 10.21428/cb6ab371.27d9e38e

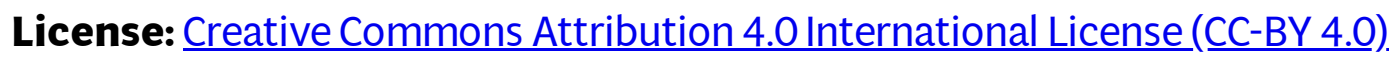


